\title{
Cell Product Encapsulation
}

National Cancer Institute

\section{Source}

National Cancer Institute. Cell Product Encapsulation. NCI Thesaurus. Code C112966.

A method that coats a cellular product with a layer of another material. 